\title{
Genetic diversity in Capsicum and Solanum genotypes based on morphoagronomic characters
}

\author{
Mayana Ferreira Nascimento ${ }^{1 *} \odot$, Fernanda Ferreira de Araújo ${ }^{1} \oplus$, Rusthon Magno Cortez dos Santos ${ }^{1} \oplus$, \\ Fernando Luiz Finger ${ }^{1} \mathbb{D}$, Claudio Horst Bruckner ${ }^{1} \mathbb{B}$ \\ 1 Universidade Federal de Viçosa, Viçosa, MG, Brasil. E-mail: mayana.f.nascimento@gmail.com; fernandaufv@hotmail.com; rusthoncortez@hotmail.com; ffinger@ufv.br; \\ bruckner@ufv.br
}

ABSTRACT: The genus Capsicum displays a wide genetic variability and studies focusing on diversity among genotypes are used in breeding programs. This study aimed to estimate the genetic variability based on morphoagronomic descriptors of pepper genotypes. The experiment was installed in a completely randomized design with 12 treatments and five replicates. The genotypes were evaluated for nine morphological and horticultural traits. The analysis of genetic divergence among the genotypes was determined by multivariate techniques, based on principal components and cluster analysis, via hierarchical grouping with average linkage (Unweighted Pair-Group Method using Arithmetic Mean - UPGMA). All quantitative descriptors were significant at 1 and $5 \%$ by the F-test. Principal component analysis showed that the first two major components accumulated $70 \%$ of the total variance. The UPGMA grouping method delineated five distinct groups, indicating the existence of genetic variability among the studied genotypes. The genotypes that gathered attributes of relevant ornamental value were 'Pirâmide ornamental', 'Tabasco' and 'Malagueta'. The most promising genotypes for fresh consumption were 'Dedo de moça', 'Rocoto vermelha', 'Rocoto amarela' and 'Jalapeño'. These genotypes present the potential to be used in breeding programs of pepper plants for ornamental purposes.

Key words: breeding; chilli peppers; genetic variability

\section{Diversidade genética em genótipos de Capsicum e Solanum com base em caracteres morfoagronômicos}

RESUMO: O gênero Capsicum apresenta ampla variabilidade genética, a diversidade disponível entre os genótipos pode ser utilizada para uso de informações em programas de melhoramento. 0 objetivo do trabalho foi estimar a variabilidade genética com base em descritores morfoagronômicos de genótipos de pimenta. $O$ experimento foi instalado no delineamento inteiramente casualizado, com 12 tratamentos e cinco repetições. Os genótipos foram avaliados quanto a nove características morfoagronômicas. A análise de divergência genética foi determinada pelas técnicas multivariadas, baseadas em análise de componentes principais e análise de agrupamento, via agrupamento hierárquico com ligação média (Unweighted PairGroup Method using Arithmetic Mean - UPGMA). Todos os descritores quantitativos estudados foram significativos em $1 \mathrm{e}$ $5 \%$, pelo teste $\mathrm{F}$. A análise de componentes principais mostrou que os dois primeiros componentes principais acumularam $70 \%$ da variância total. 0 método de agrupamento de UPGMA propiciou a formação de cinco grupos distintos, indicando a existência de variabilidade genética entre os genótipos. Os genótipos que reuniram atributos de relevante valor ornamental foram 'Pirâmide ornamental', 'Tabasco' e 'Malagueta'. Os genótipos mais promissores para consumo in natura foram 'Dedo de moça', 'Rocoto vermelha', 'Rocoto amarela' e 'Jalapeño'. Esses genótipos têm potencial para serem utilizados em programas de melhoramento de plantas de pimenta com fins ornamentais.

Palavras-chave: melhoramento; pimenta; variabilidade genética

\footnotetext{
* Mayana Ferreira Nascimento - E-mail: mayana.f.nascimento@gmail.com (Corresponding author)

Associate Editor: Alberto Cargnelutti Filho
} 


\section{Introduction}

Chilli peppers are considered one of the most important vegetables in the world and it is due to their high nutritional value and pungency of fruits. Peppers have become more popular among consumers, with applications both in industries (Xiao-min et al., 2016) and in the ornamental plants market (Rêgo \& Rêgo, 2018).

Pepper fruits are an excellent source of health-related metabolites, such as ascorbic acid (vitamin C), carotenoids, tocopherols (vitamin E), flavonoids, and capsaicinoids (Bogusz et al., 2018). Capsaicinoids are compounds found on Capsicum genus and responsible for the hot taste of the fruits, which can differ between or within species, as well as over the fruit tissues (Wahyuni et al., 2011).

The use of potted plant peppers in the decoration of indoor environments and gardens has been increasing in recent years. For this specific use, the plants must have a small size and a canopy proportional to their height. Moreover, characteristics such as fast growth and longer post-production shelf life should be selected in breeding programs for ornamental purposes (Finger \& Pereira, 2016; Rêgo \& Rêgo, 2018).

The restriction for the use of peppers as ornamental is the fact that only a limited range of varieties is suitable for growing in small pots. Such restrictions can be circumvented via genetic breeding (Fortunato et al., 2019). Increasing the frequency of favorable alleles in a single genotype is the biggest challenge in breeding programs (Pessoa et al., 2019). The knowledge on genetic variability degrees via divergence analysis provides important parameters to both identify specific potentials for each genotype and select individuals that can be used in breeding programs; in addition, it allows verifying the existence of accessions with ornamental potential based on the characteristics of interest in ornamental peppers (Baba et al., 2016).

Quantitative and qualitative characteristics are used to assess the diversity among pepper genotypes and different techniques are used to quantify genetic variability between parents. Among them, the analysis of main components and grouping are two techniques widely used when the outputs are a set for multiple response variables (Cruz et al., 2012).

The principal component analysis is a multivariate technique that allows reducing a large set of likely correlated response variables into a smaller set of representative ones that collectively explain most of the variance containing in original data (James et al., 2013). Cluster analysis, on the other hand, aims to genetically discriminate cultivars. The genotypes are grouped according to some measure of dissimilarity, in which the similar individuals are clustered into the same group and divergent ones in different clusters (Cruz et al., 2012).

This study aimed to estimate the genetic variability of pepper genotypes based on morphoagronomic descriptors and evaluate their genetic diversity via main components with subsequent cluster analysis.

\section{Materials and Methods}

The experiment was carried out in a greenhouse at the experimental field of the Agronomy Department from the Universidade Federal de Viçosa ( $20^{\circ} 45^{\prime} 47^{\prime \prime}$ LS and $42^{\circ} 49^{\prime} 13^{\prime \prime}$ LW), over 2017. The experiment was installed in a completely randomized design, with 12 treatments and five repetitions. The experimental unit consisted of one plant per pot.

Treatments consisted of eleven commercial Capsicum genotypes: 'Pérola negra' and 'Jalapeño' (C. annuum); 'Chilli', 'Tabasco', 'Strombolli ornamental', 'Pirâmide Ornamental' (C. frutescens); 'Rocoto vermelha' and 'Rocoto amarela' ( $C$. pubescens); 'Dedo de moça' (C. baccatum), 'Bode vermelha' and 'Biquinho vermelha' ( $C$. chinense) and a Solanum: Peloteira (Solanum pseudocapsicum).

Seeds were sown in 200 cell polystyrene trays, containing commercial substrate (Bioplant ${ }^{\circledR}$ ). When the seedlings presented four pairs of leaves, one single plantlet was transplanted into a $700 \mathrm{ml}$ pot number $13(10 \mathrm{~cm}$ in height, $9 \mathrm{~cm}$ in basal diameter and $12 \mathrm{~cm}$ in diameter). Culture management recommended for this species was carried out when necessary.

At the commercial stage, plants with $30 \%$ of ripe fruits were characterized based on the descriptors for Capsicum from the International Plant Genetic Resources Institute (IPGRI, 1995). Quantitative characteristics including plant height $(\mathrm{cm})$, canopy diameter $(\mathrm{cm})$, first bifurcation height $(\mathrm{cm})$, stem diameter $(\mathrm{cm})$, number of leaves per plant (count), fruit length $(\mathrm{cm})$, fruit width $(\mathrm{cm})$, number of fruits per plant (count) and production (based on fruit number and weight) were evaluated.

To quantify the genetic variability existing in the descriptors, genotypic variance, phenotypic variance and heritability were separately analyzed via analysis of variance with random effects for genotypes. The phenotypic correlation coefficients between the nine traits were estimated. The analysis was processed at 1 and $5 \%$ probability with the computer program Genes software (Cruz, 2013).

For the analysis of genetic diversity among the genotypes, principal component analysis (PCA) was used. Subsequently to PCA, the genotypes were grouped via the unweighted pair group method with arithmetic mean (UPGMA). As a measure of dissimilarity between the pairs of genotypes, the Euclidean distance was used. PCA and UPGMA were obtained with the R software (R Core Team, 2015).

\section{Results and Discussion}

ANOVA data analysis showed significant differences by the F-test $(p<0.01)$ for all analyzed characters (Table 1$)$. There is genetic variability among the genotypes for the analyzed characters (Figure 1), which allows further exploitation of this variability in pepper breeding programs. The knowledge of diversity among Capsicum species provides substantial elements about the variability that exists among and within populations, to subsequently support breeding programs (Costa et al., 2016; Fortunato et al., 2019). 
Table 1. Average square, heritability and variation coefficient for nine quantitative characters in Capsicum pepper plants.

\begin{tabular}{cccccccccc}
\hline \multirow{2}{*}{$\begin{array}{c}\text { Source } \\
\text { of variation }\end{array}$} & APH & CD & FBH & SD & NL & FL & FD & NF \\
\hline Treatment & $1191.2^{* *}$ & $801.8^{* *}$ & $392.4^{* *}$ & $0.084^{* *}$ & $14110.6^{* *}$ & $11.5^{* *}$ & $2.98^{* *}$ & $3314.08^{* *}$ & $5429.09^{* *}$ \\
$\mathrm{~h}^{2}(\%)$ & 95.7 & 96.3 & 94.1 & 95.1 & 91.7 & 97.3 & 98.4 & 94.2 & 74.5 \\
$\mathrm{CVg} / \mathrm{CVe}$ & 2.11 & 2.29 & 1.79 & 1.97 & 1.48 & 2.67 & 3.55 & 1.78 & 0.76 \\
\hline
\end{tabular}

APH - Plant height; CD - canopy diameter; FBH - first bifurcation height; SD - stem diameter; NL - number of leaves; FL - fruit length; FW - fruit diameter; NF - number of fruits; P fruit production; "ns", "*" and "**" indicates not significant and significant at $5 \%$ and $1 \%$ probability, respectively, by the test $F$. $h^{2}-$ Heritability.
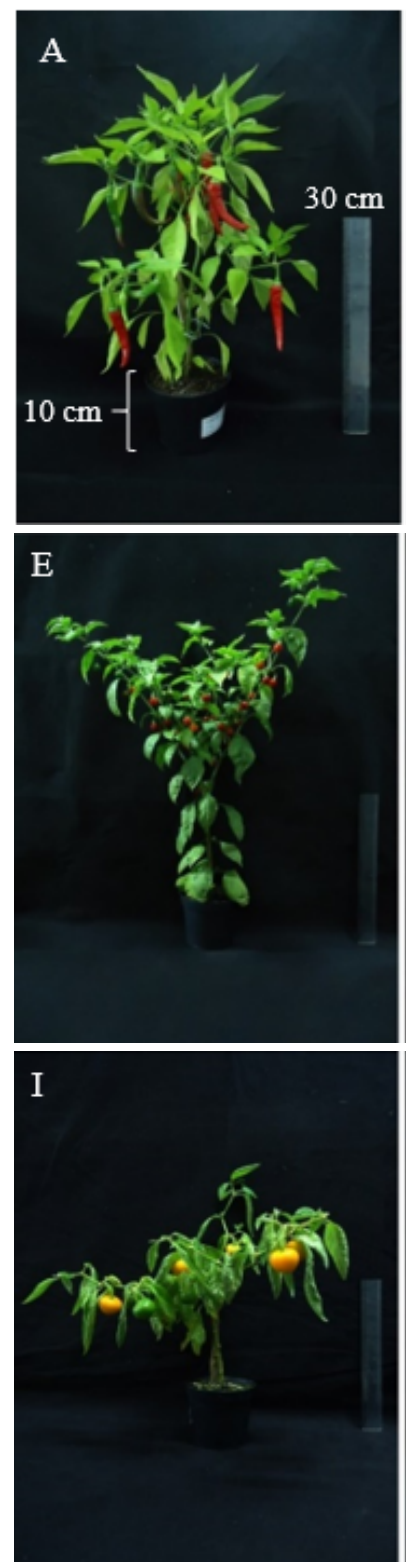
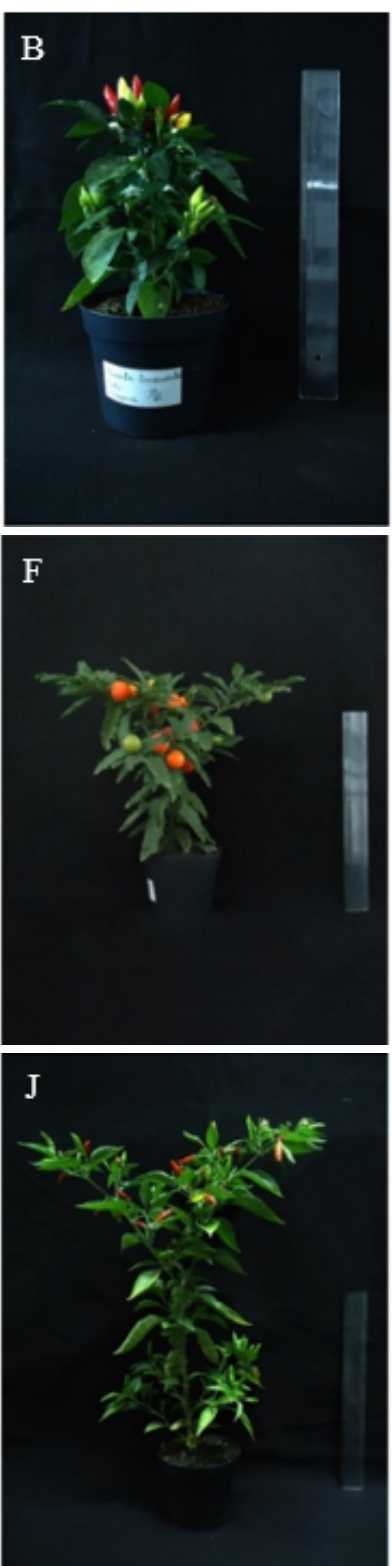
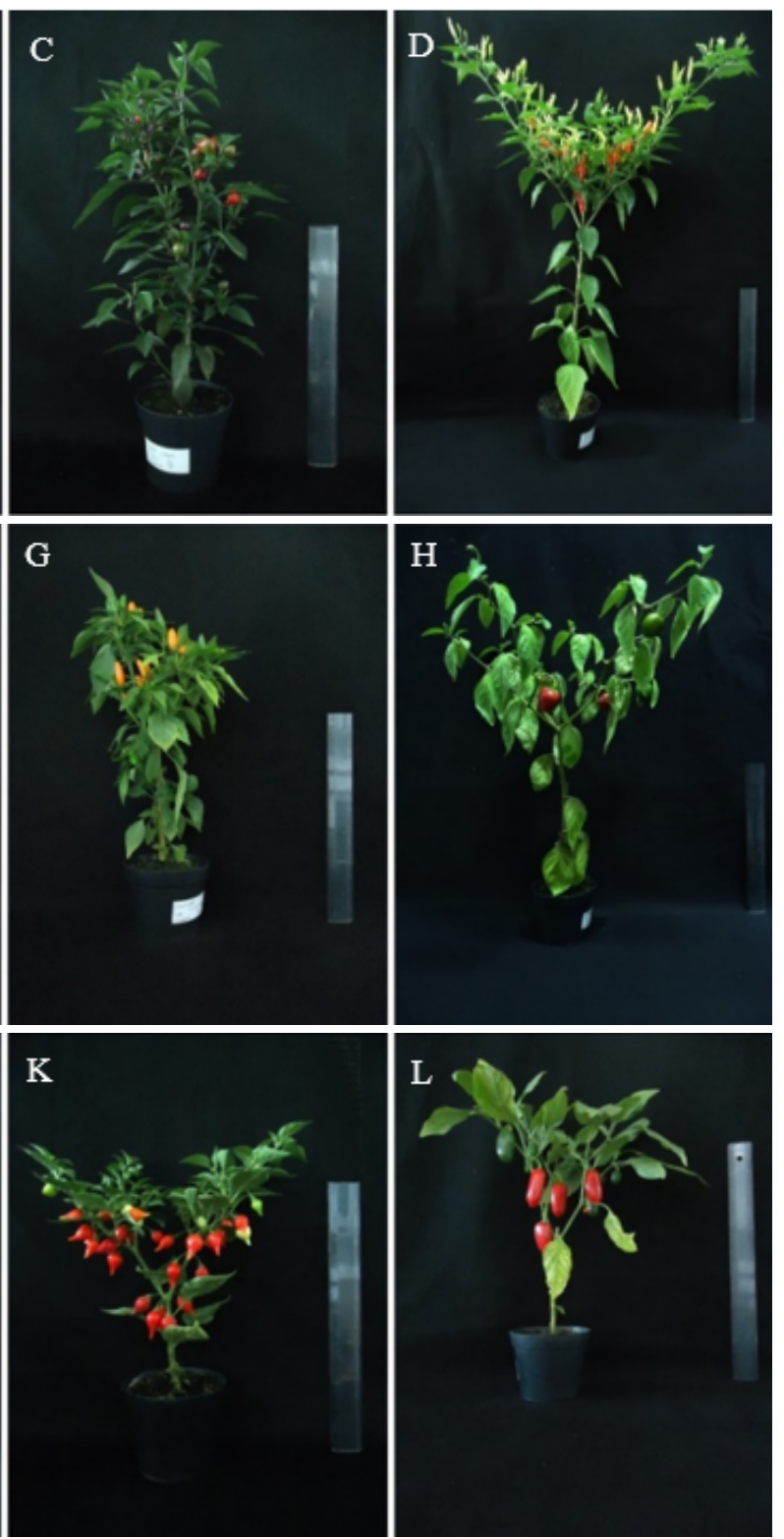

Figure 1. Pepper genotypes. A - Dedo de moça (C. baccatum); B - Pirâmide ornamental (C. frutescens); C - Pérola Negra (C. annuum); D - Tabasco (C. frutescens); E - Bode Vermelha (C. chinense); F - Peloteira (S. pseudocapsicum); G - Strombolli ornamental (C. frutrscens); $\mathrm{H}$-Rocoto vermelha (C. pubescens); I-Rocoto amarela (C. pubescens); J - Malagueta (C. frutescens); $\mathrm{K}$ - Biquinho vermelha (C. chinense); L - Jalapeño (C. annuum).

Heritability accounted for more than $90 \%$ for all characteristics, except for production, $74 \%$ (Table 1). Heritability is a parameter that indicates how much of the genetic proportion of each character will be transmitted to the next generation. High values of heritability are extremely important for the accuracy in the selection of genotypes based on the evaluated characteristics. Similar results to those demonstrated in the present study were reported by Pessoa et al. (2018).

The relationship between the coefficient of genetic and environmental variation ( $\mathrm{CVg} / \mathrm{CVe})$ was higher than 1 for all characteristics, except for the fruit production variable. Pessoa et al. (2018), in a study with C. annuum, reported CVg/ CVe values above 1 for the evaluated characteristics. 
Results concerning phenotypic correlation coefficients are shown in Table 2. The plant height showed a significant positive correlation with the first bifurcation height, stem diameter, and number of leaves. The stem diameter is an important characteristic for ornamental pepper plants since thicker stems benefit the plant support, and thus it seems suitable that plant height is correlated with stem diameter. Silva et al. (2016), by evaluating the correlation among pepper characteristics, also determined a positive correlation between plant height and stem diameter.

The canopy diameter also showed a positive correlation with the diameter of fruits (Table 2). First bifurcation height was positively correlated with stem diameter, number of leaves and number of fruits per plant. These characters should be in harmony with the pot, thus the pepper plants can present better conditions for commercialization. Neitzke et al. (2016) evaluated the consumer's preference concerning seventeen accessions of ornamental peppers and observed that plant architecture, number and contrasting color of fruits regarding the foliage are the most important attributes in the choice of an ornamental pepper.

Positive and significant correlations were also observed between number of leaves (NF) and number of fruits (NF) (Table 2). Leaves and fruits are traits of interest in ornamental peppers. A higher number of leaves leads to a denser canopy and suitable contrast with fruits, making pepper plants more attractive to consumers. According to Hachmann et al. (2014), as higher the leaf area, higher the active photosynthetic surface. Therefore, more photoassimilates are available for fruit production. Such results corroborate those observed in this study.

The fruit diameter (FD) showed a significant negative correlation with the number of fruits (NF) (Table 2). According to Streck et al. (1998), the limiting range of fruit growth depends on the number of fruits that compete for assimilates produced by the plant. Therefore, the higher the number of fruits in the plant, the smaller the diameter. Similar results have been reported by Aklilu et al. (2016) and Rêgo et al. (2011), in studies about characters association in Capsicum.

Principal component analyzes indicate that the first two components explained $70 \%$ of the variability contained in the original variables (Figure 2). Regazzi (2000) emphasizes

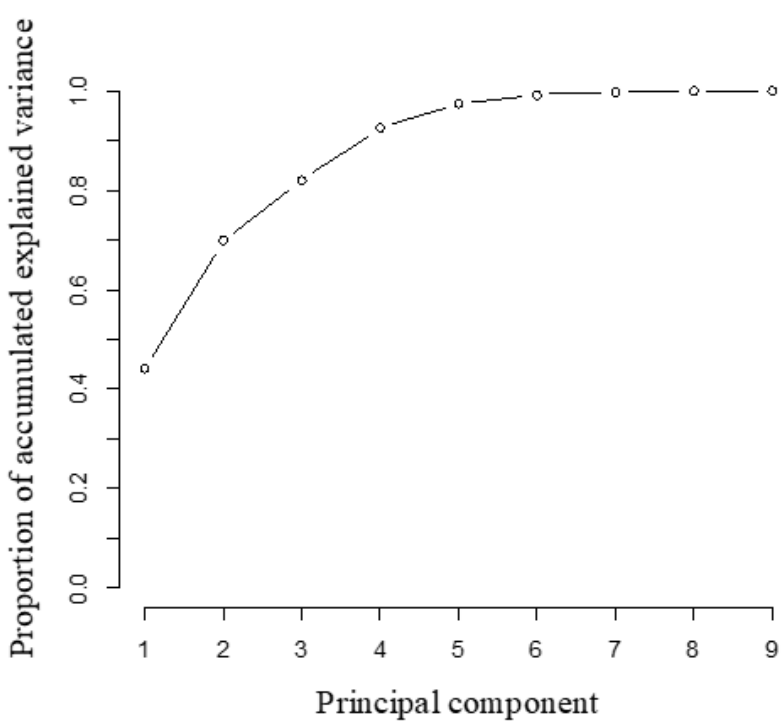

Figure 2. Scree plot of the variances explained by the two main components in peppers.

that, for applications in different areas of knowledge, it is recommended the use of components that accumulates $70 \%$ or more of the proportion from the total variance. Similar results were reported by Oliveira et al. (2019), studying the genetic diversity of 65 Capsicum accessions, in which it was observed that the first two variables explained $86 \%$ of the total genetic variation.

Using the two-dimensional dispersion analysis, the genotypes were distributed in different regions of the graph - but separated into groups at the same time (Figure 3). The variables plant height (APH), first bifurcation height (FBH), number of leaves (NF), and number of fruits (NF) presented the highest values for the main component 1 , representing the characters with the greatest weight for the variability observed in this component. In the second main component, the variables fruit diameter (FD) and canopy diameter (CD) showed the highest values (Figure 3 ).

The stem diameter (SD), plant height (APH) and first bifurcation height $(\mathrm{FBH})$ characteristics are close together, demonstrating a correlation among them. The same correlation was observed for number of leaves (NL) and number of fruits (NF), and between fruit diameter (FD) and canopy diameter (CD) (Figure 3).

Table 2. Estimation of the phenotypic correlation coefficients between nine morphoagronomic characteristics in 12 pepper genotypes.

\begin{tabular}{|c|c|c|c|c|c|c|c|c|c|}
\hline & APH & $C D$ & FBH & SD & NL & $\mathrm{FL}$ & FD & NF & $\mathbf{P}$ \\
\hline $\mathrm{APH}$ & 1 & 0.3718 & $0.9602 * *$ & $0.6955^{*}$ & $0.6204^{*}$ & -0.0349 & -0.1269 & 0.5546 & 0.2615 \\
\hline$C D$ & & 1 & 0.2224 & 0.5705 & -0.0242 & 0.0174 & $0.7421 * *$ & -0.1822 & 0.3377 \\
\hline FBH & & & 1 & $0.6043^{*}$ & $0.6581^{*}$ & -0.0350 & -0.2895 & $0.6317^{*}$ & 0.1792 \\
\hline $\mathrm{NL}$ & & & & & 1 & -0.3788 & -0.4706 & $0.8427 * *$ & 0.3305 \\
\hline $\mathrm{FL}$ & & & & & & 1 & -0.0116 & -0.2194 & 0.0660 \\
\hline $\mathrm{P}$ & & & & & & & & & 1 \\
\hline
\end{tabular}

APH - Plant height; CD - canopy diameter; FBH - first bifurcation height; SD - stem diameter; NL - number of leaves; FL - fruit length; FD - fruit diameter; NF - number of fruits; P fruit production; "*” and “**”, significant at $5 \%$ and $1 \%$ probability, respectively. 


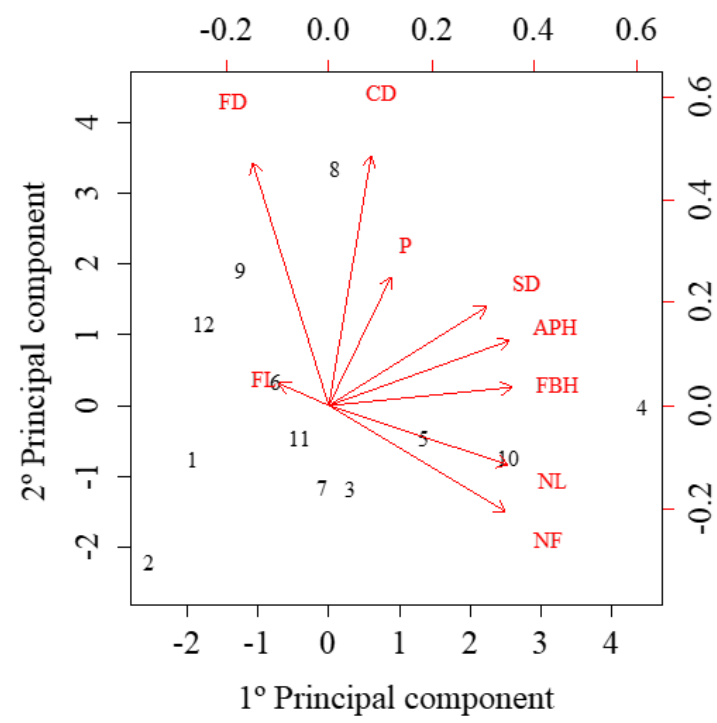

Figure 3. Two-dimensional scatter plot obtained from the first two main components using twelve genotypes of Capsicum spp. 1 (Dedo de moça); 2 (Pirâmide ornamental); 3 (Pérola Negra); 4 (Tabasco); 5 (Bode vermelha); 6 (Peloteira); 7 (Stromboli ornamental); 8 (Rocoto vermelha); 9 (Rocoto amarela); 10 (Malagueta); 11 (Biquinho vermelha); 12 (Jalapeño).

Both genotypes 4, 'Tabasco', and 10, 'Malagueta', presented the highest value in the main component 1 , thereby showing the highest plant height, first bifurcation height, number of leaves and number of fruits (Figure 3 ). The height of the ideal plant for ornamentation is also determined by the size of the pot. For used pots in this experiment, ornamental peppers should hold a maximum height of $32 \mathrm{~cm}$ (Veiling, 2021), thus these genotypes do not present potential as a potted ornamental plant. The suitable density of leaves and fruits for ornamental pepper plants is elementary; in this case, it is possible to use this genotype in future breeding programs to reduce plant size or for landscaping use purposes.

Genotypes 8 'Rocoto Vermelha' and 9 'Rocoto amarela' showed higher values for the main component 2, with higher values for fruit diameter and canopy diameter (Figure 3). Ornamental pepper plants must hold a canopy that covers the pot and shape proportional to the plant and pot size (Pessoa et al., 2019; Rego \& Rêgo, 2018). The size of the fruit is not a decisive factor in the choice of ornamental pepper by consumers. In addition to the plant's architecture, the number and contrasting color of the fruits within the foliage are the main buyers' preferred traits (Neitzke et al., 2016).

Genotype 2, 'Pirâmide Ornamental' showed the lowest values for the first and second main components. Thus, it was the genotype with the lowest plant height, first bifurcation height, number of leaves, number of fruits, fruit diameter and canopy diameter. In addition, it was plotted more distant from the other genotypes over the dispersion graph, thereby suggesting that is more divergent from the other genotypes concerning the evaluated characteristics (Figure 3).

According to commercialization patterns and the preference of a large part of consumers, the ideotype of an ornamental pepper must present a dwarf and upright size, a compact and filled with foliage crown, besides a high number of fruits contrasting within the foliage. Based on the results presented in Figure 3 , it is worth mentioning that the evaluated characteristics were efficient in distinguishing the most divergent genotypes. Each one with its peculiarities, thereby holding characteristics that meet the demands of the consumer market. Therefore, the combination of these alleles is an option to further obtain cultivars with an ornamentation ideotype.

The results of the cluster analysis via Medium Link-UPGMA Method (Figure 4) were similar to the graphical dispersion analysis (Figure 3). The genotypes were grouped into five distinct groups, considering the cut-off point of 3 (Figure 4). The formation of these groups can support breeders during contrasting parents' selection to assesses hybrid combinations for better heterosis exploitation (Cruz et al., 2012). These results are in close agreement with previously reported studies on genetic diversity among Capsicum peppers (Pessoa et al., 2018; Fortunato et al., 2019; Santos et al., 2019), indicating that the morphological descriptors are efficient for genotypes discrimination regarding genetic diversity.

Group I comprised genotypes from the species $C$. chinense (Biquinho vermelha e bode vermelha), $C$. frutescens (Strombolli Ornamental), C. annuum (Pérola Negra) and Pseudocapsicum (Peloteira) (Figura 4).

Genotype 2, 'Pirâmide Ornamental' (C. frutescens), was isolated from the other genotypes in group II (Figure 4), as shown in the two-dimensional projection (Figure 3). Probably because it is a genotype with more divergent characteristics as compared to its counterparts. The 'Pirâmide Ornamental' holds essential attributes for ornamental uses of pepper, such as dwarf size and low bifurcation height.

Group III consisted of genotypes 1 and 12, C. baccatum and $C$. annuum, respectively (Figure 4 ). Although they are

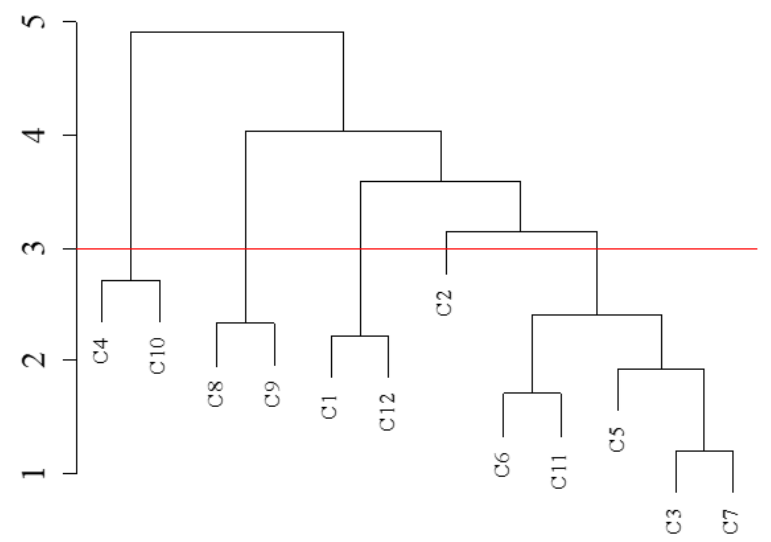

Figure 4. Dendrogram for cluster analysis of twelve pepper genotypes by the medium link method (UPGMA), using the Euclidean distance, obtained from the analysis of nine quantitative characters. C1 - Dedo de moça; C2 - Pirâmide ornamental; C3 - Pérola Negra; C4 - Tabasco; C5 - Bode Vermelha; C6 - Peloteira; C7 - Stomboli ornamental; C8 Rocoto vermelha; C9 - Rocoto amarela; C10 - Malagueta; C11 - Biquinho vermelha; C12 - Jalapeño. 
different species, they have similar characteristics related to the vegetative growth of plants and fruits. The fruits from 'Dedo de Moça' and 'Jalapeño' are widely consumed, either fresh or processed, due to their increased length and diameter. Ornamental peppers producing fruits with length and diameters as proportional to their size aggregates value to the product due to its dual purpose, since the fruits can be also consumed.

Group IV gathered genotypes 8 and 9, both belonging to the $C$. pubescens species, which were very similar to each other, differing in some qualitative characteristics, such as growth habit and fruit color at both intermediate and ripening stages. These genotypes have a large canopy and few fruits. However, their fruits are ideal for the production of preserves, sauces, or powdered paprika, as they contain a great portion of pericarp and a high degree of heat (Meckelmann et al., 2015).

Group V is formed by the genotypes 4 and 10, 'Tabasco' and 'Malagueta' peppers, respectively, both belonging to the C. frutescens species (Figure 4). 'Tabasco' and 'Malagueta' peppers are widely consumed in Brazil. Due to their relatively high degree of heat, their production is intended for either consumption in natura or as sauces and preserves (Lima et al., 2017). However, according to the established pattern from Veiling Holambra cooperative (Veiling Holambra, 2021), they have no potential for ornamentation growing in pots used in this study. The introduction of these genotypes in genetic breeding programs would add value to the product. The new cultivars could be used for decoration and their fruits for fresh consumption, like sauces or preserves.

Although we have used a relatively small number of genotypes in this analysis, they showed high variability for the analyzed characteristics. Identifying the dissimilarity or similarity of studied genotypes - associated with suitable characteristics for ornamental peppers - is of utmost importance for breeding programs that seek to develop new cultivars based on demands and preferences of the consumers.

\section{Conclusion}

There is genetic variability among the evaluated pepper genotypes based on morphoagronomic characters, which allows a further selection of divergent material with potential uses in breeding programs for both potted ornamental pepper and fruit consumption.

Genotypes 2, 4 and 10 present relevant attributes as ornamental cultivars.

Genotypes 1, 12, 8 and 9 are better adapted for in natura consumption.

\section{Acknowledgment}

To the National Development Council (CNPq) and the Coordination for the Improvement of Higher Education Personnel (Capes) for financial support.

\section{Compliance with Ethical Standards}

Author contributions: Conceptualization: MFN, FLF; Data curation: MFN; Formal Analysis: RMCS; Funding acquisition: FLF, CHB; Investigation: MFN; Methodology: MFN, FLF, CHB; Project administration: MFN, FLF; Resources: FLF, CHB; Supervision: FLF, CHB; Visualization: MFN; Writing - original draft: MFN; Writing - review \& editing: MFN, FFA.

Conflict of interest: The authors declare that there are no personal, commercial, academic, political, and financial conflicts of interest in the manuscript.

Financing source: The Conselho Nacional de Desenvolvimento Científico e Tecnológico (CNPq) and the Coordenação de Aperfeiçoamento de Pessoal de Nível Superior - Brasil (CAPES) - Finance Code 001,

\section{Literature Cited}

Aklilu, S.; Abebie, B.; Wogari, D.; Wolde, A.T. Genetic variability and association of characters in Ethiopian hot pepper (Capsicum annum L.) Landraces. Journal of Agricultural Sciences, v.61, n.1, p.19-36, 2016. https://doi.org/10.2298/JAS1601019A.

Baba, V.Y.; Rocha, K.R.; Gomes, G.P.; Ruas, C.F.; Ruas, P.M.; Rodrigues, R.; Gonçalves, L.S.A. Genetic diversity of Capsicum chinense accessions based on fruit morphological characterization and AFLP markers. Genetic Resources and Crop Evolution, v.63, n.8, p. 1371-1381, 2016. https://doi.org/10.1007/s10722-015-0325-4.

Bogusz, S.; Libardi, S.H; Dias, F.F.; Coutinho, J.P.; Bochi, V.C.; Rodrigues, D.; Melo, A.M.; Godoy, H.T. Brazilian Capsicum peppers: capsaicinoids content and antioxidant activity. Journal of the Science of Food and Agriculture, v.98, n.1, p.217-224, 2018. https://doi.org/10.1002/jsfa.8459.

Costa, M.P.S.D.; Rêgo, M.M.; Silva, A.P.G.; Rêgo, E.R.; Barroso, P.A. Characterization and genetic diversity of pepper (Capsicum spp.) parents and interspecific hybrids. Genetics and Molecular Research, v.15, n.1, p.1- 12, 2016. https://doi.org/10.4238/ gmr.15027652.

Cruz, C.D. GENES: a software package for analysis in experimental statistics and quantitative genetics. Acta Scientiarum. Agronomy, v.35, n.3, p.271-276, 2013. https://doi.org/10.4025/actasciagron. v35i3.21251.

Cruz, C.D.; Regazzi, A.J.; Carneiro, P.C.S. Modelos biométricos aplicados ao melhoramento genético. Viçosa: Universidade Federal de Viçosa, 2012. 514p.

Finger, F.L.; Pereira, G.M. Physiology and postharvest of pepper fruits. In: Rêgo, E.R.; Rêgo, M.M.; Finger, F.L. (Eds.). Production and breending of Chilli peppers (Capsicum spp). Berlin: Springer International Publishing, 2016. Chap. 2, p. 27-40. https://doi. org/10.1007/978-3-319-06532-8_2.

Fortunato, F.L.G.; Rêgo, E.R.; Carvalho, M.G.; Santos, C.A.P.; Rêgo, M.M. Genetic diversity in ornamental pepper plants. Comunicata Scientiae, v.10, n.3, p. 364-375, 2019.

Hachmann, T.L.; Echer, M.M.; Dalastra, G.M.; Vasconcelos, E.S.; Guimarães, V.F. Tomato cultivation under different spacing and different levels of defoliation of basal leaves. Bragantia, v.73, n.4, p. 399-406, 2014. https://doi.org/10.1590/1678-4499.0163. 
International Plant Genetic Resources Institute - IPGRI. Descriptors for Capsicum. Rome: IPGRI, 1995. 51p.

James, G.; Witten, D.; Hastie, T.; Tibshirani, R. An Introduction to statistical learning: with applications in R. New York: Springer, 2013. 426p. https://doi.org/10.1007/978-1-4614-7138-7.

Lima, M.F.; Carvalho, S.I.C.; Ragassi, C.F.; Bianchetti, L.B.; Faleiro, F.G.; Reifschneider, F.J.B. Characterization of a pepper collection (Capsicum frutescens L.) from Brazil. Genetics and Molecular Research, v.16, n.3, gmr16039704, 2017. https://doi. org/10.4238/gmr16039704.

Meckelmann, S.W.; Jansen, C.; Riegel, D.W.; Zonneveld, M.V.; Ríos, L.; Peña, K.; Mueller-Seitz, E.; Petz, M. Phytochemicals in native Peruvian Capsicum pubescens (Rocoto). European Food Research and Technology, v.241, p.817-825, 2015. https://doi. org/10.1007/s00217-015-2506-y.

Neitzke, R.S.; Fischer, S.Z.; Vasconcelos, C.S.; Barbieri, R.L.; Treptow, R.O. Pimentas ornamentais: aceitação e preferências do público consumidor. Horticultura Brasileira, v.34, n.1, p.102-109, 2016. https://doi.org/10.1590/S0102-053620160000100015.

Oliveira, C.S.; Peixoto, J.V.M.; Momesso, M.P.; Pereira, L.M.; Peres, H.G.; Maciel, G.M. Características de plântulas: dissimilaridade genética entre acessos de pimenta. Ciência, Tecnologia \& Ambiente, v.9, n.1, e09114, 2019. https://doi.org/10.4322/23596643.09114.

Pessoa, A.M.S.; Rêgo, E.R.; Carvalho, M.G.; Santos, C.A.P.; Rêgo, M.M. Genetic diversity among accessions of Capsicum annuum L. through morphoagronomic characters. Genetics and Molecular Research, v.17, n.1, gmr16039883, 2018. https://doi. org/10.4238/gmr16039883.

Pessoa, A.M.S.; Rêgo, E.R.; Santos, C.A.P.; Carvalho, M.G.; Mesquita, J.C.P.; Rêgo, M.M. Potential of pepper plant accessions for ornamental purposes using diallel analysis. Anais da Academia Brasileira de Ciências, v.91, n.4, e20180379, 2019. https://doi. org/10.1590/0001-3765201920180379.

R Core Team. R: a language and environment for statistical computing. Vienna: R Core Team, 2015.

Regazzi, A.J. Análise multivariada. v.2. Viçosa: Departamento de Informática; Universidade Federal de Viçosa, 2000. (Notas de aula - INF 766).
Rêgo, E.R.; Rêgo, M.M.; Cruz, C.D.; Finger, F.L.; Casali, V.W.D. Phenotypic diversity, correlation and importance of variables for fruit quality and yield traits in Brazilian peppers (Capsicum baccatum). Genetic Resources and Crop Evolution, v.58, p.909918, 2011. https://doi.org/10.1007/s10722-010-9628-7.

Rêgo, E.R.; Rêgo, M.M. Ornamental pepper. In: Van Huylenbroeck, J (Ed.). Ornamental Crops. Cham: Springer International Publishing, 2018. Chap. 22, p.529-565. (Handbook of Plant Breeding, 11). https://doi.org/10.1007/978-3-319-90698-0_22.

Santos, T.O.; Moulin, M.M.; Rangel, L.H.; Pirovani, R.O.L.; Valadares, F.V.; Almeida, R.N.; Silva, L.O.E. Characterization and diversity of peppers (Capsicum spp.) genotypes based on morphological traits using multivariate analysis. Journal of Experimental Agriculture International, v.39, n.1, p. 1-10, 2019. https://doi. org/10.9734/jeai/2019/v39i130325.

Silva, A.R.; Rêgo, E.R.; Pessoa, M.A.S.; Rêgo, M.M. Correlation network analysis between phenotypic and genotypic traits of chili pepper. Pesquisa Agropecuária Brasileira, v.51, n.4, p.372-377, 2016. https://doi.org/10.1590/S0100-204X2016000400010.

Streck, N.A.; Buriol, G.A.; Andriolo, J.L.; Sandri, M.A. Influência da densidade de plantas e da poda apical drástica na produtividade do tomateiro em estufa de plástico. Pesquisa Agropecuária Brasileira, v.33, n.7, p.1105-1112, 1998. http://seer.sct.embrapa. br/index.php/pab/article/download/4940/7068. 13 May. 2021.

Veiling Holambra - Flores e Plantas Ornamentais. Critérios de classificação pimenta ornamental. http://veiling.com.br/ uploads/padrao/pimenta-ornamental-po.pdf. 08 Jun. 2021.

Wahyuni, Y.; Ballester, A.R.; Sudarmonowati, E.; Bino, R.J.; Bovy, A.G. Metabolite biodiversity in pepper (Capsicum) fruits of thirty-two diverse accessions: Variation in health-related compounds and implications for breeding. Phytochemistry, v.72, n.11-12, p.13581370, 2011. https://doi.org/10.1016/j.phytochem.2011.03.016.

Xiao-min, Z.; Zheng-hai, Z.; Xiao-zhen, G.; Sheng-li, M.; Xi-xiang, L.; Chadoeuf, J.; Palloix, A.; Li-hao, W.; Zhang, Bao-xi. Z. Genetic diversity of pepper (Capsicum spp.) germplasm resources in China reflects selection for cultivar types and spatial distribution. Journal of Integrative Agriculture, v.15, n.9, p.1991-2001, 2016. https://doi.org/10.1016/S2095-3119(16)61364-3. 